\title{
Evaluation of content of phenolics in Salvia species cultivated in South Moravian Region Hodnotenie obsahu fenolov vo vybraných druhoch rodu Salvia L. pestovaných v Juhomoravskom kraji
}

\author{
${ }^{1}$ Mendel University in Brno, \\ Faculty of Horticulture, Department of Vegetable \\ Growing and Floriculture, Czech Republic \\ ${ }^{2}$ Agricultural Research, Ltd. Troubsko, Czech Republic
}

Muráriková A. ${ }^{\square}$, Kaffková K. ${ }^{1}$, Raab S. ${ }^{2}$, Neugebauerová J. ${ }^{1}$

${ }^{1}$ Mendelova univerzita v Brně, Zahradnická fakulta,

Ústav zelinářství a květinářství, Česká republika

²Zemědělský výzkum, spol. s r.o. Troubsko, Česká republika

Received November 30, 2014, accepted January 30, 2015

Abstract In this study, total phenolic content (TPC) and rosmarinic acid (RA) of 37 samples sage (Salvia L.) of extracts were determined using spectrophotometric methods. The amount of total phenols was analysed with Folin-Ciocalteu reagents. Gallic acid was used as a standard compound and the total phenols were expressed as $\mathrm{mg} \cdot \mathrm{g}^{-1}$ gallic acid equivalents of dried plant material. The values of the extracts displayed substantial differences. All of the investigated species except Salvia jurisicii (990.79 mg GAE. $\mathrm{g}^{-1}$ d.w.) exhibited higher content of phenolics. Among the studies, species demonstrated the highest content of phenol, followed in sequence by Salvia tomentosa, Salvia fruticosa, Salvia triloba, Salvia officinalis 'Extrakta', Salvia officinalis. TPC varied from 990.79 to 4459.88 mg GAE. $\mathrm{g}^{-1} \mathrm{~d}$.w. in the extracts. The total amount of RA was between 0.88 and $8.04 \%$ among species. Salvia tomentosa, Salvia verticillata and Salvia officinalis'Extrakta' had the highest content of RA. The high content of phenolic compounds indicated that these compounds contribute to the antioxidant activity.

Slovak V štúdii na celkový obsah fenolových látok a kyseliny rozmarínovej bolo hodnotených 37 vzoriek šalvie (Salvia L.) z metanolových abstract extraktov stanovených spektrofotometricky. Množstvo celkových fenolov bolo analyzované s pomocou Folin Ciocalteuového

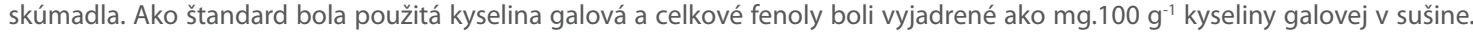
Boli zobrazené podstatné rozdiely hodnotených extraktov. Všetky skúmané druhy okrem Salvia jurisici (990,79 mg GAE.100 g ${ }^{-1}$ ) vykazovali vyšší obsah fenolových látok. Najvyšší obsah fenolov vykazovali v poradí Salvia tomentosa, Salvia fruticosa, Salvia triloba, Salvia officinalis 'Extrakta' a Salvia officinalis. Celkový obsah fenolových látok sa pohyboval v rozmedzí od 990,79 do 4459,88 mg GAE.100 g-1 . Celkové množstvo kyseliny rozmarínovej bolo v rozpätí 0,88 až 8,04 \%. Druhy Salvia tomentosa, Salvia verticilla a Salvia officinalis 'Extrakta' mali najvyšší obsah kyseliny rozmarínovej. Vysoký obsah fenolových zlúčenín indikuje, že tieto zlúčeniny prispievajú k antioxidačnej kapacite.

Keywords sage-Salvia L. - phenolic compounds - rosmarinic acid - south Moravian region

Klúčové Šalvia-Salvia L. - fenolové látky - kyselina rozmarínová-juhomoravský kraj

slová:

\section{INTRODUCTION}

The genus Salvia includes about 900 species that grow in several regions all over the world (Kintzios, 2000). Sage is one of the oldest medicinal plants used by human (Muntean et al., 2007). Sage has been traditionally used in medicines, flavours and fragrances (Demirci et al., 2003). Curative properties of sage are particularly recognised since earliest times at is use a tonic, stimulant, carminative, antiseptic and antihydrotic is reported (Kintzios, 2000).
Plants belonging to the Lamiaceae family are very rich in polyphenolic compounds. Sage has been observed to have excellent properties that inhibit lipid peroxidation and this activity is attributed principally to the presence of phenolic compounds (Cuvelier et al., 1996; Lu \& Foo, 2001). The major phenolic compounds identified in the extracts of sage are rosmarinic acid (RA), carnosic acid, salvianolic acid and its derivatives carnosol, rosmanol, epirosmanol, rosmadial and

*E-mail:xmurarik@node.mendelu.cz

(c) Acta Facultatis Pharmaceuticae Universitatis Comenianae 
methyl carbonate (Cuvelier et al., 1996; Lu \& Foo, 2001; Madsen et al., 1995). Due to the variability of environmental factors, the phenolic containing extracts obtained from different sage samples show great differences in composition and consequently, differences in antioxidative power (Cuvelier et al., 1996; Areias et al., 2000).

RA is a water-soluble ester of 3,4- dihydroxycinnamic acid and 3,4 dihydroxyphenyllactate. It is found mainly in the family of Lamiaceae, although it has also been described in other plant families such as Apiaceae. RA is the major phenol compounds of sage, also found in many other plants used as seasoning (Petersen \& Simmonds 2003). RA has been reported to have antiviral, antibacterial, antihepatitis, antimutagenic, antiallergic, anticarcinogenic and anti-inflammatory properties (Ito et al. 1998; Cao et al. 2005).

In this study, the content of phenolic and RA from Salvia L. samples from Czech Republic were investigated.

\section{MATERIAL AND METHODS}

\section{Plant material}

The plant material (aerial parts) was collected on two locations in the Czech Republic in South Moravian Region (Lednice and Troubsko) from May to July of 2012. The plant material was dried in bundles, in the shade in an airy place and then stored in paper bags and kept at room temperature.

\section{Chemicals}

Folin-Ciocalteu's reagent, sodium carbonate, distilled water, ethanol, hydrochloric acid, sodium nitrate, sodium molybdate, sodium hydroxide

\section{Extract preparation}

Dry and pulverised plant material (5 g) was extracted using $75 \%$ methanol. The samples were filtered after 24 hours of extraction at room temperature with filter paper (Shan et al., 2005). The obtained extracts were kept in sample tubes and stored in a refrigerator.

\section{Analysis of total phenolics}

Total phenolic content (TPC) was determined using FolinCiocalteu's method. The appropriate amount of filtered methanol extracts were oxidised with Folin-Ciocalteu's reagents and after 5 minutes, the reaction was neutralised with saturated sodium carbonate. The resulting blue complex was then measured at $756 \mathrm{~nm}$ after 90 minutes of incubation at room temperature. Gallic acid was used as the standard and the contents of phenolics were expressed as g gallic acid equivalents (GAE.100 $\mathrm{g}^{-1}$ d.w.).

\section{Analysis of rosmarinic acid}

Stock solution: To $0.200 \mathrm{~g}$ of the powdered drug, add $80 \mathrm{ml}$ of ethanol $(50 \% \mathrm{~V} / \mathrm{V}) \mathrm{R}$. Boil in a water-bath under a reflux condenser for 30 minutes. Allow to cool and filter. Rinse the filter with $10 \mathrm{ml}$ of ethanol $(50 \%$ V/V) R. Combine the filtrate and the rinsings in a volumetric flask and dilute to $100.0 \mathrm{ml}$ with ethanol ( $50 \% \mathrm{~V} / \mathrm{V}) \mathrm{R}$.

Test solution: To $1.0 \mathrm{ml}$ of the stock solution add $2 \mathrm{ml}$ of $0.5 \mathrm{M}$ hydrochloric acid, $2 \mathrm{ml}$ of a solution prepared by dissolving 10 $\mathrm{g}$ of sodium nitrite $\mathrm{R}$ and $10 \mathrm{~g}$ of sodium molybdate $\mathrm{R}$ in 100 $\mathrm{ml}$ of water $\mathrm{R}$ and then add $2 \mathrm{ml}$ of dilute sodium hydroxide solution $\mathrm{R}$ and dilute to $10.0 \mathrm{ml}$ with water $\mathrm{R}$; mix.

Compensation solution: Dilute $1.0 \mathrm{ml}$ of the stock solution to $10.0 \mathrm{ml}$ with water R. Measure immediately the absorbance of the test solution at $505 \mathrm{~nm}$.

\section{RESULTS AND DISCUSSION}

The results of TPC of Salvia species are shown in Table 1 and Figure 1. Content of RA are shown in Table 1 and Figure 2.

The TPC of the samples were determined at 1441.26$5136.70 \mathrm{mg} \mathrm{GAE} .100 \mathrm{~g}^{-1}$ d.w. Extract of Salvia jurisicii exhibits the lowest phenolic content (1441.26 mg GAE.100 g ${ }^{-1}$ d.w.) and the concentration of RA (0.88\%). Plant extract of Salvia tomentosa had higher phenolic content $(5136.70 \mathrm{mg}$ GAE. $100 \mathrm{~g}^{-1}$ d.w.) and the concentration of RA (8.04\%).

Authors Tosun et al. (2009) investigated the content of total phenols in eight species of sage. The amount of the total phenolics was highest in Salvia verticillata (167.1 mg GAE.100 g d.w.), followed by Salvia virgata (101.2 mg GAE.100 g d.w.) and Salvia candidissima (100.3 mg GAE.100 g d.w.). Salvia microstegia had the lowest TPC $(50.3 \mathrm{mg}$ GAE.100 $\mathrm{g}$ d.w.). Several studies have been carried out with the Salvia species and TPC has been found to be between 41-134 mg GAE.100 g d.w. basis (Kosar et al., 2008; Ogutcu et al., 2008). The results are comparable to those obtained by Miliauskas et al. (2004), who studied some culinary plants and obtained ranges of $4.30-37.90 \mathrm{mg}$. GAE.100 g. Total content of phenolic compounds in Salvia sclarea extracts was $24.0 \pm 1.1$ (mg GAE.100 g d.w.). Wagensteen et al. (2004) obtained $19 \mathrm{mg}$ GAE.100 g total phenolic compounds in some coriander plants. Ismail et al. (2004) detected ranges of 11.07-71.67 mg in GAE.100 g selected vegetables. Variation of phenolic compounds content arises due to several factors, which include the area of cultivation and other environmental stresses (Makkar, 1999).

RA content in sage plants grown in other countries was reported in literature. In research Bandoniene et al., (2005), the content of RA in dried leaves of the sage species were 13.3-47.3 mg.100 g. Salvia glutinosa and Salvia sclarea had the highest concentration of RA. The presence of RA was also reported in field - grown as well as various in-vitro cultures 
Evaluation of content of phenolics in Salvia species cultivated in South Moravian Region

Table 1. Total phenolic content and rosmarinic acid in 37 samples of sage

\begin{tabular}{|c|c|c|c|c|}
\hline No. & Scientific name & Growing area & TPC [mg GAE.100 g-1] d.w. & $\begin{array}{c}\text { RA } \\
\text { [\%] }\end{array}$ \\
\hline 1. & Salvia officinalis spp. lavandulifolia & Troubsko & 3017.08 & 3.1942 \\
\hline 2. & Salvia coccinea & Troubsko & 3407.53 & 3.6872 \\
\hline 3. & Salvia virgata & Lednice & 2181.63 & 4.4509 \\
\hline 4. & Salvia fruticosa & Troubsko & 2758.92 & 3.5657 \\
\hline 5. & Salvia tomentosa & Troubsko & 5136.70 & 8.0377 \\
\hline 6. & Salvia pratensis & Troubsko & 2573.34 & 2.8315 \\
\hline 7. & Salvia pratensis & Troubsko & 1853.09 & 3.0208 \\
\hline 8. & Salvia transsylvanica & Lednice & 1723.99 & 1.7669 \\
\hline 9. & Salvia amplexicaulis & Troubsko & 2959.13 & 3.7507 \\
\hline 10. & Salvia verticillata & Troubsko & 2351.14 & 4.7440 \\
\hline 11. & Salvia nemorosa ssp. tesquicola & Lednice & 3055.43 & 2.6245 \\
\hline 12. & Salvia argentea & Troubsko & 1232.71 & 1.1440 \\
\hline 13. & Salvia verticillata & Troubsko & 2814.64 & 5.5786 \\
\hline 14. & Salvia tilifolia & Troubsko & 1675.88 & 2.0976 \\
\hline 15. & Salvia aethiopsis & Troubsko & 2095.31 & 1.7017 \\
\hline 16. & Salvia reflexa & Troubsko & 2442.06 & 2.7001 \\
\hline 17. & Salvia officinalis & Lednice & 3699.76 & 4.7746 \\
\hline 18. & Salvia aethiopis & Troubsko & 1934.45 & 2.2794 \\
\hline 19. & Salvia nemorosa 'Rosenwein' & Troubsko & 2242.00 & 3.5474 \\
\hline 20. & Salvia fruticosa & Lednice & 4208.93 & 3.5252 \\
\hline 21. & Salvia nemorosa 'Blaukönogin' & Troubsko & 2723.48 & 4.4589 \\
\hline 22. & Salvia pratensis & Troubsko & 2019.42 & 2.6790 \\
\hline 23. & Salvia azurea & Troubsko & 3280.25 & 3.6280 \\
\hline 24. & Salvia kopetdaghensis & Troubsko & 2258.25 & 3.4739 \\
\hline 25. & Salvia officinalis 'Krajová' & Troubsko & 3226.07 & 3.7312 \\
\hline 26. & Salvia officinalis & Troubsko & 3247.35 & 3.3207 \\
\hline 27. & Salvia jurisicii & Troubsko & 1441.26 & 1.0443 \\
\hline 28. & Salvia jurisicii & Troubsko & 990.79 & 0.8809 \\
\hline 29. & Salvia transcaucasica & Troubsko & 1589.25 & 3.4137 \\
\hline 30. & Salvia nemorosa & Troubsko & 2386.01 & 2.7090 \\
\hline 31. & Salvia nemorosa 'Violetkönigin' & Ledncie & 2298.70 & 3.1573 \\
\hline 32. & Salvia cadmica & Troubsko & 2579.21 & 3.4794 \\
\hline 33. & Salvia officinalis 'Extrakta' & Lednice & 3905.49 & 5.0139 \\
\hline 34. & Salvia pratensis & Lednice & 2411.13 & 2.9563 \\
\hline 35. & Salvia triloba & Lednice & 3922.15 & 4.3200 \\
\hline 36. & Salvia officinalis 'Extrakta' & Lednice & 3178.62 & 3.4880 \\
\hline 37. & Salvia sclarea 'Vatican White' & Lednice & 2980.74 & 3.7251 \\
\hline
\end{tabular}

TPC: total phenolic content, RA: rosmarinic acid 


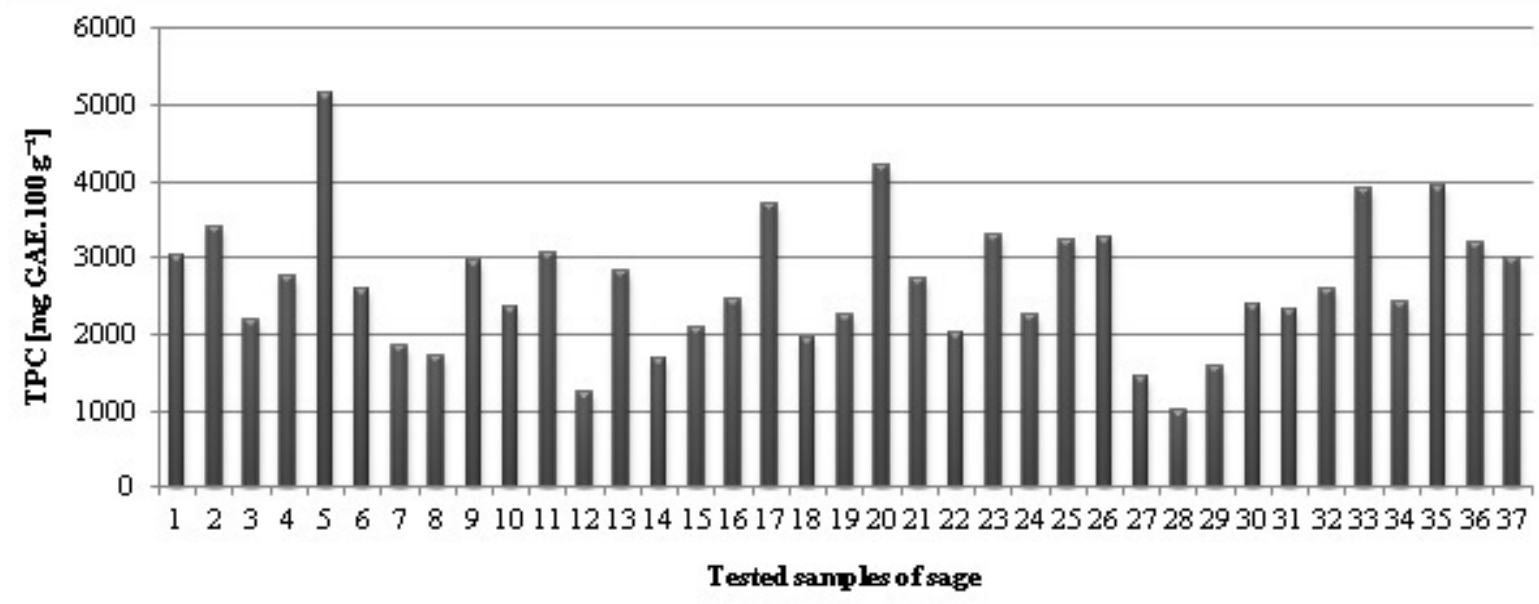

Figure 1. Total phenolic content (\%) in tested samples TPC: total phenolic content

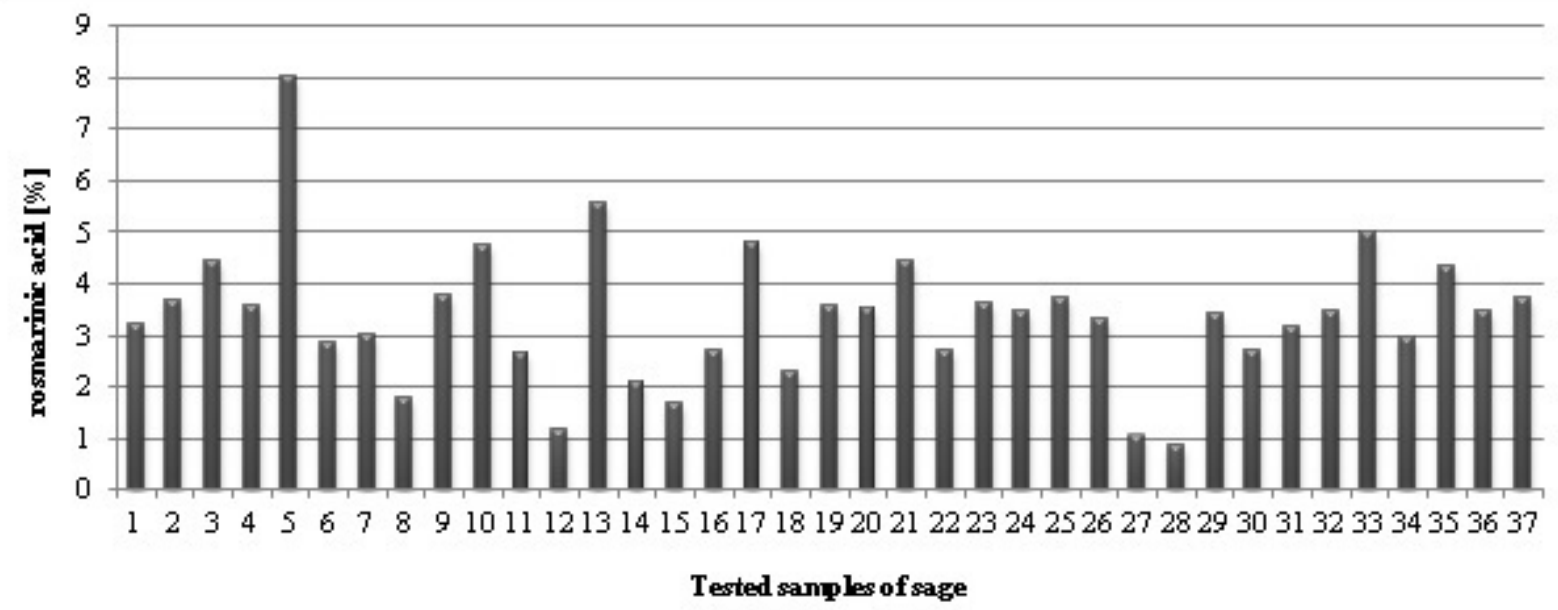

Figure 2. The content of rosmarinic acid (\%) in tested samples

of Salvia officinalis plants originating in Poland. The content of RA in that study was about 1.2-1.9\% (Grzegorczyk et al., 2007).

\section{CONCLUSION}

In conclusion, methanol extract of sage grown in Lednice and Troubsko has high content of phenolic compounds. Extract of Salvia jurisicii exhibits the lowest phenolic content $(990.79 \mathrm{mg}$ GAE. $100 \mathrm{~g}^{-1}$ d.w.). Plant extract of Salvia tomentosa has higher phenolic content (5136.70 mg GAE.100 g ${ }^{-1}$ d.w.). The total amount of RA was between 0.88 and $8.04 \%$ among species. Mainly, extracts of Salvia tomentosa, Salvia fruticosa, Salvia triloba, Salvia officinalis 'Extrakta', Salvia officinalis can be used as natural antioxidants.

\section{ACKNOWLEDGEMENTS}

Thisstudywassupported bygrantOPVKCZ.1.07/2.4.00/31.0089 of the Ministry of Education of the Czech Republic.

\section{References}

[1] Areias F, Valentao P, Andrade PB, Ferres F, Seabra RS. Flavonooids and phenolic acids of sage: Influence of some agricultural factors. J. Agric Food Chem. 2000;48:6081-6084.

[2] Bandoniene D, Murkovic M, Venskutonis PR. Determination of Rosmarinic Acid in Sage and Borage Leaves by Hight-
Performance Liquid Chromatography with Different Detection Methods. J Chromatogr Sci. 2005;43:372-376.

[3] Cao H, Cheng WX, Li C, Pan XL, Xie XG, Lie TH. DFT study on the antioxidant activity of rosmarinic acid. J.Mol. Struct. 2005;719:177-183. 
[4] Cuvelier ME, Richard H, Berset C. Antioxidative activity and phenolic composition of pilot-plant and commercial extracts of sage and rosemary. J. Am. Oil Chem. Soc. 1996;79:645-652.

[5] Demirci B, Baser HC, Yildiz B, Bahcecioglu Z. Composition of the essential oils of six endemic Salvia spp. from Turkey. Flavour Frag. J. 2003;18:116-121.

[6] Grzegorzyk I, Matkowski A, Wysokinska H. Antioxidant activity of extract from in vitro cultures of Salvia officinalis L. Food Chem. 2007; 104:536-541.

[7] Ismail A, Marjan ZM, Foong CW. Total antioxidant activity and phenolic contents in selected vegetables. Food Chem. 2004;87:581-586.

[8] Ito $H$, Miyazaki T, Ono $M$, Sakurai $H$. Antiallergic activities of rabdosiin and its related compounds: Chemical and biochemical evaluations. Bioorg. Med. Chem. 1998;6:1051-1056.

[9] Kintzios SE. Sage: The Genus Salvia. Amsterdam, Md: CRC Press; 2000.

[10] Kosar M, Goger F, Baser KHC. In vitro antioxidant properties and phenolic composition of Salvia virgata Jacq. from Turkey. J. Agric. Food Chem. 2008;56:2369-2374.

[11] Lu Y, Foo LY. Salvianolic acid. A potent phenolic antioxidant from Salvia officinalis. Tetrahedron Letters. 2001;42:8223-8225.

[12] Madsen HI, Bertelsen G. Spices as antioxidant. Trends in Food Science and Technology. 1995;6:271-277.
[13] Makkar HPS. Quantification of tannins in tree foliage: A laboratory manual for FAO/IAEA. Joint FAO/IAEA Division of Nuclear Techniques in Food and Agriculture, Vienna, 1999; p. 1-29.

[14] Miliauskas S, Venskunones PR, Van Beek TA. Screening of radical scavenging activity of some medicinal plant extracts. Food Chem. 2004;85:231-237.

[15] Muntean LS, Tamas M, Muntean S, Muntean L, Duda MM, Vârban DI, Florian S. Tratat de plante medicinale cultivate şi spontane. Cluj-Napoca, Md: Risoprint; 2007.

[16] Petersen M, Simmonds MSJ. Rosmarinic acid. Phytochemistry. 2003;62:121-125.

[17] Ogutcu H, Sokmen A, Sokmen M, Polissiou M, Serkedjieva J, Daferera D, Sahin F, Baris O, Gulluce M. Bioactivities of the various extracts and essential oils of Salvia limbata C.A. Mey and Salvia sclarea L.. Turkish Journal of Biology. 2008;32:181-192.

[18] Shan B, Cai YZ, Mei S, Corke H. Antioxidant Capacity of 26 spice extracts and characterization of their phenolic constituents. J. Agric. Food Chem. 2005;53:7749-7759.

[19] Tosun M, Ercisli S, Sengul M, Ozer H, Polat T, Ozturk E. Antioxidant Properties and Total Phenolic Content of Eight Salvia Species from Turkey. Biol. Res. 2009;42:175-181.

[20] Wagensteen H, Samuelsen BA, Malterude EK. Antioxidant activity in extracts from coriander. Food Chem. 2004;88:293-297. 